\title{
Rевевсн автіске: Attitude towards ICT utilization and its influencing variables among the agricultural officers in Andhra Pradesh
}

\author{
T. SRI CHANDANA, P.V. SATHYA GOPAL, V. SAILAJA AND A.V. NAGAVANI
}

Article Chronicle : Received : 17.07.2017;

Accepted : 01.08 .2017

KeY Words: Attitude, Agricultural Officers, Information, Communication technology

Author for correspondence :

T. SRI CHANDANA Department of Agricultural Extension, S.V. Agricultural College, (A.N.G.R.A.U.), TIRUPATI (A.P.) INDIA

Email: talarisrichandana 39@gmail.com
SUMMARY : Information technology is a key to agricultural development. The use of information and communication technology (ICT) is becoming progressively more widespread throughout various sectors including education, business as well as agriculture. ICTs are all technologies used for the widespread transfer and sharing of information. Hence, the present investigation was carried out in Nellore, Srikakulam, Ananthapur districts purely covering all the three regions viz., Coastal Andhra, North Coastal and Rayalaseema regions in the newly formed state of Andhra Pradesh. The main objective of the study was to measureattitude towards ICT utilization and the relationship between selected profile characteristics of Agricultural Officers and attitude towards ICT utilization. Ex post facto research design was followed for the study. A total 120 respondents covering the three districts equally were selected for the study.It was found that nearly one third (31.66\%) of the Agricultural Officers had neutral attitude towards ICT utilization followed by 20.84 per cent of them had shown moderately unfavourable, 19.16 per cent of them had moderately favourable attitude and about 15.84 had highly unfavourable attitude. On the other side, highly favourable attitude towards ICT utilization was noticed by nearly 12.50 per cent of the Agricultural Officers. 'Updating knowledge', 'Technology transfer', 'Unimaginable information', 'Global knowledge sharing', 'Time saving', these five concepts ranked from first to fifth respectively followed by 'Widens vision', 'Interest in ICT', 'Speedy delivery of information', 'Browsing time', 'Global development', 'Vital for extension growth' ranked from sixth to eleventh and 'Difficulty in understanding', 'Gravity of information', 'Oral face to face' 'Self-thinking', 'Practicality', 'Plagiarism' and 'Monotony'ranked from twelfth to eighteenth respectively are the critical concepts that contributed for positive attitude towards ICT utilization by the Agricultural Officers. The relationship between selected profile characteristics and their attitude towards ICT utilization indicated that job autonomy, convenience of posting, possession of communication gadgets, organizational climate and job satisfactionwere positively significant related. Further, the selected twelve independent variables put together explained about 51.24 per cent variation in theattitude towards ICT utilization.

How to cite this article : Chandana, T. Sri, Gopal, P.V. Sathya, Sailaja, V. and Nagavani, A.V. (2017). Attitude towards ICT utilization and its influencing variables among the agricultural officers in Andhra Pradesh. Agric. Update, 12(TECHSEAR-6) : 1537-1542; DOI: 10.15740/HAS/AU/12.TECHSEAR(6)2017/1537-1542. 